\title{
A randomised controlled comparison of tiotropium and ipratropium in the treatment of chronic obstructive pulmonary disease
} J A van Noord, Th A Bantje, M E Eland, L Korducki, P J G Cornelissen, on behalf of the
Dutch Tiotropium Study Group
Department of Respiratory Diseases, Atrium Medisch Centrum, Heerlen, The Netherlands $\mathrm{J}$ A van Noord

Department of Respiratory Diseases, Ignatius and Baronie Hospitals, Breda, The Netherlands

Th A Bantje

Department of Respiratory Diseases, Merwede Hospital, Dordrecht, The

Netherlands

M E Eland

Boehringer Ingelheim, Ridgefield, CT, USA and Alkmaar, The

Netherlands

L Korducki

P J G Cornelissen

The members of the Dutch Tiotropium Study Group include: Th A Bantje, Breda; $\mathrm{J} M \mathrm{M}$ v d Bosch,

Nieuwegein; M C M Bunnik, Boxmeer; M E Eland, Dordrecht; S J M Gans, Harderwijk; H Ch Gooszen, Eindhoven; J H L M van

Kasteren, Geldrop; J A van Noord, Heerlen; G D Nossent, Groningen; A Peters, Blaricum; W R Pieters, Helmond; P E Postmus, Amsterdam; H E J Sinninghe Damsté, Almelo; A P Sips, Utrecht.

Correspondence to: Dr J A van Noord, Department of Respiratory Diseases, Atrium Medisch Centrum, Henri

Dunantstraat 5, 6419 PC

Heerlen, The Netherlands

Received 12 July 1999 Returned to authors 27 August 1999 Revised version received 16 December 1999 Accepted for publication 16 December 1999

\section{Abstract}

Background-A study was undertaken to evaluate and compare the efficacy and safety of tiotropium and ipratropium during long term treatment in patients with stable chronic obstructive pulmonary disease (COPD).

Methods-288 patients of mean (SD) age 65 (8) years and forced expiratory volume in one second $\left(\mathrm{FEV}_{1}\right) 41(12) \%$ predicted participated in a 14 centre, double blind, double dummy, parallel group study and were randomised after a run in period of two weeks to receive either tiotropium $18 \mu \mathrm{g}$ once daily from a dry powder inhaler (HandiHaler; two thirds of patients) or ipratropium $40 \mu \mathrm{g}$ four times daily from a metered dose inhaler (one third of patients) for a period of 13 weeks. Outcome measures were lung function, daily records of peak expiratory flow (PEF), and the use of concomitant salbutamol. $\mathrm{FEV}_{1}$ and forced vital capacity (FVC) were measured one hour before and immediately before inhalation (mean value of the two measurements on test day 1 was the baseline value while on all other test days it was known as the trough $\mathbf{F E V}_{1}$ and FVC), and $0.5,1,2,3,4,5$, and 6 hours after inhalation of the study drug on days $1,8,50$, and 92 .

Results-During treatment tiotropium achieved a significantly greater improvement than ipratropium $(p<0.05)$ in trough, average, and peak $F E V_{1}$ levels and in trough and average FVC levels. The trough $\mathrm{FEV}_{1}$ response on days 8,50 , and 92 ranged between $0.151(95 \% \mathrm{CI} 0.11$ to 0.19$)$ and $0.161(95 \% \mathrm{CI} 0.12$ to 0.20$)$ for tiotropium and between $0.011(95 \% \mathrm{CI}-0.03$ to 0.05 ) and $0.031(95 \% \mathrm{CI} 0.01$ to 0.07$)$ for ipratropium. The trough FVC response on days 8, 50, and 92 ranged between 0.341 (95\% CI 0.28 to 0.40$)$ and 0.391 (95\% CI 0.31 to 0.47 ) for tiotropium and between $0.081(95 \%$ CI 0.00 to 0.16$)$ and $0.181(95 \%$ CI 0.08 to 0.28 ) for ipratropium. On all test days tiotropium produced a greater improvement in $\mathrm{FEV}_{1}$ than ipratropium starting three hours after inhalation $(p<0.05)$. During treatment weekly mean morning and evening peak expiratory flow (PEF) was consistently better in the tiotropium group than in the ipratropium group, the difference in morning PEF being significant up through week 10 and in evening PEF up through week 7 of treatment $(p<0.05)$. The use of concomitant salbutamol was also lower in the tiotropium group $(p<0.05)$. The only drug related adverse event was dry mouth (tiotropium $14.7 \%$, ipratropium $10.3 \%$ of patients).

Conclusions-Tiotropium in a dose of $18 \mu \mathrm{g}$ inhaled once daily using the HandiHaler was significantly more effective than $40 \mu \mathrm{g}$ ipratropium four times daily in improving trough, average, and peak lung function over the 13 week period. The safety profile of tiotropium was similar to ipratropium. These data support the use of tiotropium as first line treatment for the long term maintenance treatment of patients with airflow obstruction due to COPD.

(Thorax 2000;55:289-294)

Keywords: tiotropium; ipratropium; chronic obstructive pulmonary disease; anticholinergic agents

In patients with chronic obstructive pulmonary disease (COPD) bronchodilators are the first line approach to treatment. ${ }^{1}$ The spirometric response to bronchodilators such as $\beta_{2}$ agonists, anticholinergic agents and methylxanthines is, at best, very modest. However, even in the absence of significant bronchodilation an improvement in symptoms and exercise tolerance can be found. ${ }^{2}$

In COPD cholinergic vagal tone is thought to be the only reversible component of airway obstruction. ${ }^{3}$ Currently, anticholinergics feature prominently in European and American guidelines. ${ }^{14}$ The anticholinergic agent ipratropium is an effective and safe drug with few side effects and without signs of tolerance during chronic treatment. However, its duration of action is limited to $4-6$ hours and the agent is a non-selective blocker of all muscarinic receptor subtypes. ${ }^{35}$ Blocking of $\mathrm{M}_{2}$ receptors may account for some cases of paradoxical bronchoconstriction. $^{6}$

Tiotropium is a quaternary ammonium compound which is structurally related to ipratropium. In vitro work has shown that the compound has a unique kinetic selectivity for $M_{3}$ and $M_{1}$ versus $M_{2}$ receptors and dissociates 100 times more slowly than ipratropium from $\mathrm{M}_{3}$ and $\mathrm{M}_{1}$ receptors. ${ }^{78}$ Only a few clinical single dose studies have so far been published in patients with COPD and asthma, which confirm that tiotropium is a potent and long 
Table 1 Demographic and baseline characteristics of the randomised patients

\begin{tabular}{lcc}
\hline & $\begin{array}{c}\text { Tiotropium } \\
(n=191)\end{array}$ & $\begin{array}{c}\text { Ipratropium } \\
(n=97)\end{array}$ \\
\hline Sex $(\mathrm{M} / \mathrm{F})$ & $156 / 35$ & $82 / 12$ \\
Age (years) & $64(8)$ & $65(8)$ \\
Height $(\mathrm{cm})$ & $172(8)$ & $172(7)$ \\
Weight $(\mathrm{kg})$ & $74(13)$ & $74(12)$ \\
Smoking history (pack years) & $33(16)$ & $35(19)$ \\
Duration of disease (years) & $11(9)$ & $12(10)$ \\
FEV 1 (1) & $1.24(0.41)$ & $1.19(0.35)$ \\
FEV 1 (\% pred) & $42(12)$ & $40(10)$ \\
FVC (1) & $2.84(0.82)$ & $2.66(0.74)$ \\
FVC (\% pred) & $76(17)$ & $70(17)$ \\
FEV $/$ FVC (\%) & $44(11)$ & $46(10)$ \\
Prestudy medication for COPD $($ no. (\%) of patients): \\
$\quad$ Anticholinergics & $106(56)$ & $53(55)$ \\
$\beta_{2}$ agonists, inhaled & $137(72)$ & $62(64)$ \\
Steroids inhaled & $142(74)$ & $78(80)$ \\
Steroids oral & $17(9)$ & $10(10)$ \\
Theophylline & $27(14)$ & $12(12)$
\end{tabular}

Values are mean (SD). No significant differences were seen between the two groups.

$\mathrm{FEV}_{1}=$ forced expiratory volume in one second $\mathrm{FVC}=$ forced vital capacity; $\%$ pred $=$ percentage of predicted value .

Table 2 Randomised and withdrawn patients

\begin{tabular}{lcl}
\hline & Tiotropium & Ipratropium \\
\hline Total randomised and treated & $191(100)$ & $97(100)$ \\
Withdrawn because of & & \\
$\quad$ Adverse event & $14(7.3)$ & $9(9.3)$ \\
Lack of efficacy & $2(1.0)$ & $0(0)$ \\
Protocol violation & $1(0.5)$ & $0(0)$ \\
$\quad$ Other reasons & $2(1.0)$ & $2(2.1)$ \\
Completed all test days & $172(90.1)$ & $86(88.7)$ \\
\hline
\end{tabular}

Values are number (\%) of patients. No significant differences were seen between the two groups.

acting bronchodilator suited for once daily administration..$^{9-11}$ Long term studies of more than one month have not been reported. The present study was designed to evaluate and compare the efficacy and safety of tiotropium
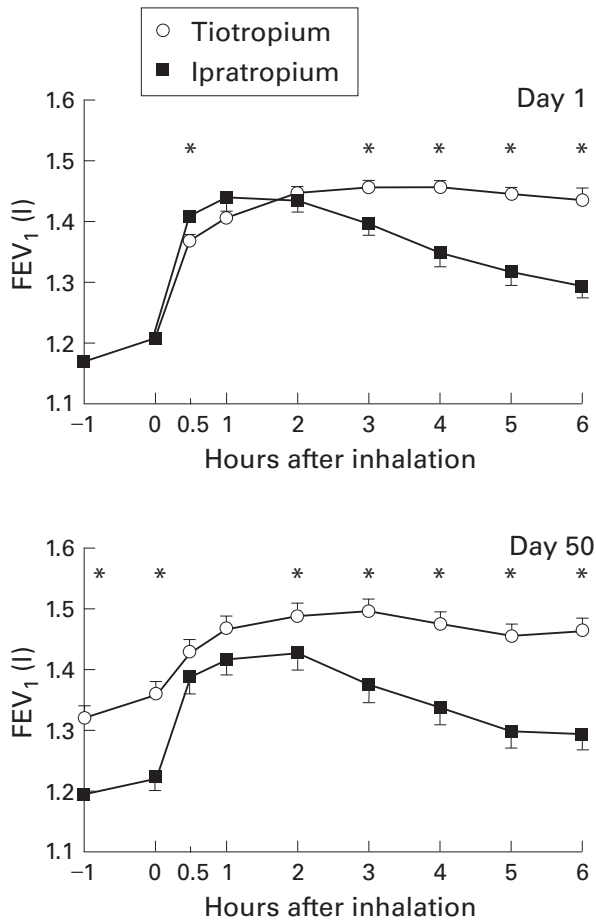

$(18 \mu \mathrm{g})$ from a dry powder inhaler (DPI) once daily and ipratropium $(40 \mu \mathrm{g})$ from a metered dose inhaler (MDI) four times daily in patients with stable, moderate to severe airway obstruction due to COPD. This study reports the first 13 weeks of a one year study with the focus on lung function.

\section{Methods}

PATIENTS

Patients were required to have a clinical diagnosis of COPD according to the ATS criteria and stable airways obstruction with forced expiratory volume in one second $\left(\mathrm{FEV}_{1}\right)$ of $<65 \%$ predicted $^{12}$ and a ratio of $\mathrm{FEV}_{1}$ to forced vital capacity (FVC) of $<70 \%$. Their age had to be at least 40 years and all had to be current or previous smokers ( $\geqslant 10$ pack years). Patients were excluded if they had a history of asthma, allergic rhinitis, atopy, or an increased total blood eosinophil count, a significant disease other than COPD, or a recent history of myocardial infarction, heart failure or cardiac arrythmia requiring drug treatment. In addition, patients were excluded if they were on oxygen therapy or had had an upper respiratory tract infection in the six weeks before screening. Patients with a known hypersensitivity to anticholinergic drugs, known symptomatic prostatic hypertrophy, and narrow angle glaucoma were also excluded.

STUDY DESIGN

Fourteen centres in the Netherlands participated in this randomised, double blind, double dummy, parallel group study which was approved by the medical ethics committees of
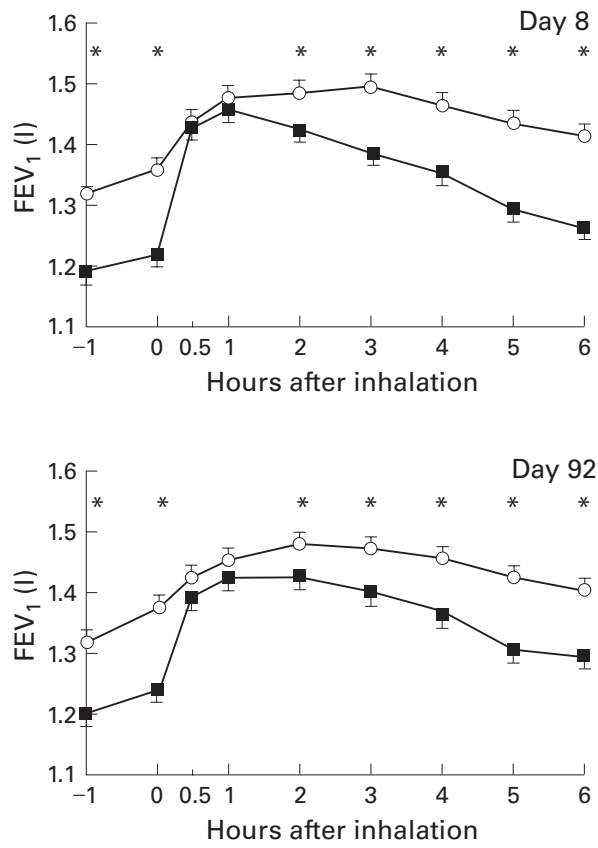

Figure 1 Mean (SE) values of forced expiratory volume in one second $\left(F E V_{1}\right)$ before and during six hours after inhalation of tiotropium and ipratropium. The baseline means are adjusted for centre effects. All other means are adjusted for centre effects and baseline FEV, (tiotropium $1.21 \mathrm{l}$, ipratropium $1.15 \mathrm{l}, \mathrm{p}>0.05$ ). The common baseline mean FEV is $1.19 \mathrm{l}$. The SE for the mean differences between treatments ranged from 0.01 to $0.02 l$ (day 1 ), 0.02 to $0.03 l$ (day 8 ), and was 0.03 l for days 50 and $92 .{ }^{\star} p<0.05$ tiotropium versus ipratropium. 
Table 3 Mean (SE) trough, peak and average (over 6 hours) response in FEV, and FVC after tiotropium and ipratropium

\begin{tabular}{|c|c|c|c|c|c|c|}
\hline & Day & $\begin{array}{l}\text { Tiotropium } \\
(n=182)\end{array}$ & $\begin{array}{l}\text { Ipratropium } \\
(n=93)\end{array}$ & Difference & $95 \% C I$ & $p$ value \\
\hline \multicolumn{7}{|l|}{$F E V_{1}$ response } \\
\hline \multirow[t]{3}{*}{ Trough (1) } & 8 & $0.15(0.01)$ & $0.01(0.02)$ & $0.13(0.02)$ & 0.09 to 0.18 & 0.0001 \\
\hline & 50 & $0.15(0.02)$ & $0.01(0.02)$ & $0.14(0.03)$ & 0.09 to 0.19 & 0.0001 \\
\hline & 92 & $0.16(0.02)$ & $0.03(0.02)$ & $0.13(0.03)$ & 0.08 to 0.18 & 0.0001 \\
\hline \multirow[t]{4}{*}{ Peak (1) } & 1 & $0.34(0.01)$ & $0.32(0.02)$ & $0.02(0.02)$ & -0.02 to 0.06 & 0.29 \\
\hline & 8 & $0.38(0.02)$ & $0.32(0.02)$ & $0.06(0.03)$ & 0.00 to 0.11 & 0.03 \\
\hline & 50 & $0.38(0.02)$ & $0.30(0.03)$ & $0.09(0.03)$ & 0.02 to 0.15 & 0.01 \\
\hline & 92 & $0.36(0.02)$ & $0.31(0.02)$ & $0.05(0.03)$ & -0.00 to 0.11 & 0.06 \\
\hline \multirow{4}{*}{ Average (1) } & 1 & $0.24(0.01)$ & $0.18(0.02)$ & $0.06(0.02)$ & 0.02 to 0.09 & 0.002 \\
\hline & 8 & $0.27(0.02)$ & $0.18(0.02)$ & $0.09(0.02)$ & 0.04 to 0.14 & 0.0002 \\
\hline & 50 & $0.28(0.02)$ & $0.17(0.02)$ & $0.11(0.03)$ & 0.05 to 0.16 & 0.0002 \\
\hline & 92 & $0.26(0.02)$ & $0.18(0.02)$ & $0.08(0.03)$ & 0.03 to 0.13 & 0.003 \\
\hline \multicolumn{7}{|c|}{ FVC response } \\
\hline \multirow[t]{3}{*}{ Trough (1) } & 8 & $0.34(0.03)$ & $0.08(0.04)$ & $0.25(0.05)$ & 0.15 to 0.35 & 0.0001 \\
\hline & 50 & $0.34(0.03)$ & $0.11(0.05)$ & $0.23(0.05)$ & 0.13 to 0.34 & 0.0001 \\
\hline & 92 & $0.39(0.04)$ & $0.18(0.05)$ & $0.21(0.06)$ & 0.10 to 0.32 & 0.0003 \\
\hline \multirow[t]{4}{*}{ Peak (1) } & 1 & $0.78(0.03)$ & $0.70(0.04)$ & $0.08(0.05)$ & -0.01 to 0.18 & 0.08 \\
\hline & 8 & $0.83(0.04)$ & $0.73(0.05)$ & $0.10(0.06)$ & -0.02 to 0.21 & 0.10 \\
\hline & 50 & $0.85(0.04)$ & $0.74(0.06)$ & $0.11(0.07)$ & -0.03 to 0.24 & 0.11 \\
\hline & 92 & $0.84(0.04)$ & $0.77(0.06)$ & $0.06(0.07)$ & -0.07 to 0.20 & 0.35 \\
\hline \multirow[t]{4}{*}{ Average (1) } & 1 & $0.53(0.03)$ & $0.40(0.03)$ & $0.13(0.04)$ & 0.05 to 0.21 & 0.001 \\
\hline & 8 & $0.58(0.03)$ & $0.42(0.05)$ & $0.16(0.05)$ & 0.06 to 0.27 & 0.003 \\
\hline & 50 & $0.62(0.04)$ & $0.45(0.05)$ & $0.17(0.06)$ & 0.05 to 0.29 & 0.006 \\
\hline & 92 & $0.61(0.04)$ & $0.50(0.05)$ & $0.11(0.06)$ & -0.01 to 0.23 & 0.08 \\
\hline
\end{tabular}

The baseline means are adjusted for centre effects. All other means are adjusted for centre effects and baseline $\mathrm{FEV}_{1}$ or FVC. The common baseline mean $\mathrm{FEV}_{1}$ is 1.191 (tiotropium 1.21 1, ipratropium 1.151, p>0.05); the common baseline mean FVC is 2.691 (tiotropium 2.75 1, ipratropium $2.571, \mathrm{p}>0.05$ ). all participating hospitals. Written informed consent was obtained from all patients before any study procedure was undertaken.

The study had a run in period of two weeks FVC measurements were performed after the first dose and after 8, 50, and 92 days of treatment. The patients continued to take the permitted medication for their COPD in stable doses, including methylxanthines, inhaled steroids, oral steroids up to $10 \mathrm{mg}$ prednisone per
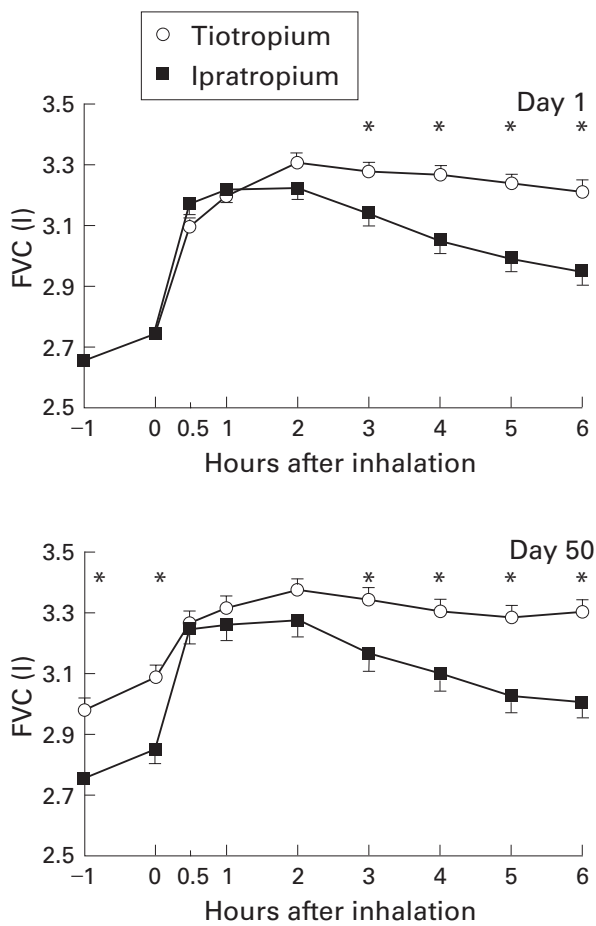
and a treatment period of 13 weeks. $\mathrm{FEV}_{1}$ and

day, and mucolytics. Long acting inhaled $\beta_{2}$ agonists, oral $\beta_{2}$ agonists, and cromolyn sodium were not allowed for at least one month before the screening visit as well as throughout the study period. Anticholinergics were allowed during the run in period but were discontinued at the randomisation visit. Patients were given open label salbutamol to use as rescue medication as necessary. They were allowed to increase or add oral steroids for two periods of seven days if necessary during exacerbations.

At the randomisation visit patients received either tiotropium $18 \mu \mathrm{g}$ once daily (Spiriva) + ipratropium matched placebo four times daily, or tiotropium matched placebo once daily + ipratropium $40 \mu \mathrm{g}$ four times daily (Atrovent). Tiotropium was inhaled from the HandiHaler, a dry powder inhaler system, ${ }^{13}$ between 08.00 and 10.00 hours. Ipratropium (two puffs of $20 \mu \mathrm{g}$ ) was inhaled from a pMDI between 08.00 and 10.00 hours, at lunch, dinner, and when going to bed. Two thirds of the patients were randomised into the tiotropium group and one third into the ipratropium group using blocks of three patients.

\section{MEASUREMENTS}

Before entry and at the completion of the study patients underwent a medical examination, laboratory testing, and a 12-lead ECG. At each scheduled visit details of clinical status, adverse events, exacerbations, and withdrawals were recorded. Pulmonary function testing started always between 08.00 and 09.00 hours. $\mathrm{FEV}_{1}$ and FVC measurements were obtained one hour before and immediately before inhalation and at $0.5,1,2,3,4,5$, and 6 hours after inha-
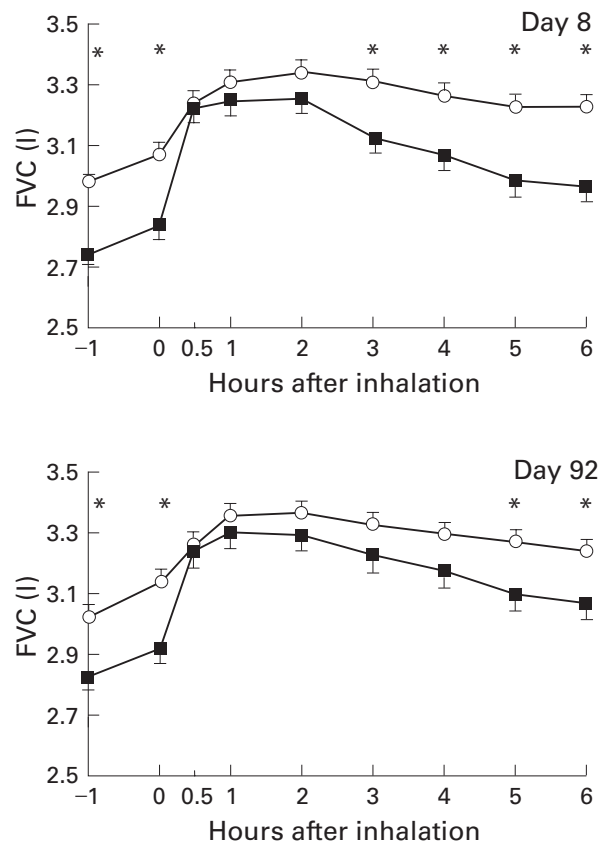

Figure 2 Mean (SE) values of forced vital capacity (FVC) before and during six hours after inhalation of tiotropium and ipratropium. The baseline means are adjusted for centre effects. All other means are adjusted for centre effects and baseline FVC (tiotropium $2.75 \mathrm{l}$, ipratropium $2.57 \mathrm{l}$, p>0.05). The common baseline mean FVC is $2.69 \mathrm{l}$. The SE for the mean differences between treatments ranged from 0.02 to $0.05 l$ (day 1), 0.05 to $0.06 l$ (day 8), 0.05 to $0.07 l$ (day 50 ), and 0.06 to $0.07 \mathrm{l}$ (day 92). ${ }^{\star} p<0.05$ tiotropium versus ipratropium. 

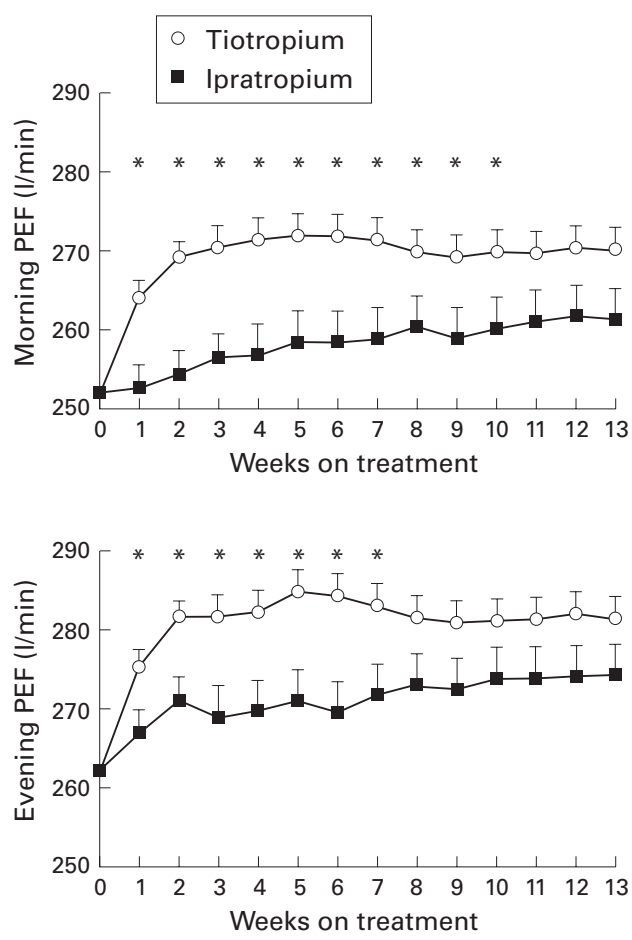

Figure 3 Mean (SE) values of morning and evening peak expiratory flow (PEF) over one week periods during treatment with tiotropium and ipratropium. The baseline means are adjusted for centre effects. All other means are adjusted for centre effects and baseline morning (tiotropium $254 \mathrm{l} / \mathrm{min}$, ipratropium $247 \mathrm{l} / \mathrm{min}, p>0.05)$ and evening PEF (tiotropium $265 \mathrm{l} / \mathrm{min}$, ipratropium $255 \mathrm{l} / \mathrm{min}$, $p>0.05)$. The common baseline mean morning PEF is $252 \mathrm{l} / \mathrm{min}$ and evening PEF is $262 \mathrm{l} / \mathrm{min} .{ }^{*} p<0.05$ tiotropium versus ipratropium.

lation of the trial drug. These measurements were performed with a spirometer meeting ATS criteria. ${ }^{14}$ The highest values of $\mathrm{FEV}_{1}$ and FVC from three technically adequate measurements were retained. Short acting theophyllines were withheld at least 24 hours, long acting theophyllines at least 72 hours, and short acting $\beta_{2}$ agonists and inhaled steroids 12 hours before the pulmonary function test.

During the run in and treatment periods patients completed a daily diary card recording their morning and evening peak expiratory flow

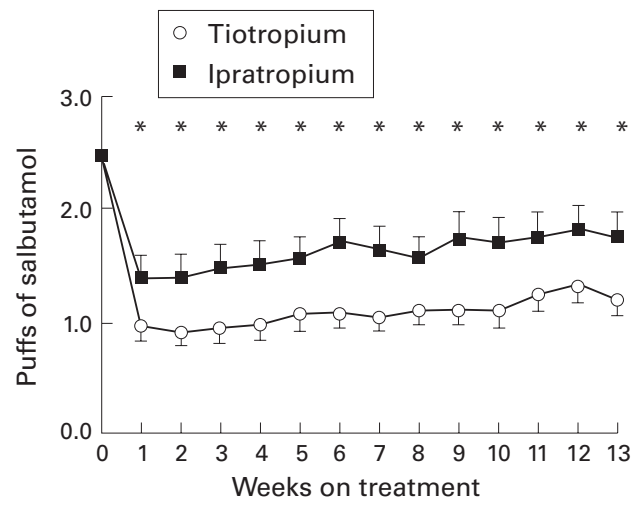

Figure 4 Mean (SE) doses of supplemental salbutamol per day over one week periods during treatment with tiotropium and ipratropium. The baseline means are adjusted for centre effects. All other means are adjusted for centre effects and baseline value (tiotropium 2.7 puffs, ipratropium 2.2 puffs, $p>0.05$ ). The common baseline mean puffs per day is 2.5. ${ }^{\star} p<0.05$ tiotropium versus ipratropium.
(PEF) and the use of concomitant salbutamol. PEF was measured using a mini-Wright peak flow meter immediately upon arising and before the inhalation of the study drugs and at bedtime before inhalation of the last daily dose. The best of three measurements was retained.

\section{STATISTICAL ANALYSIS}

Analysis of covariance was used, with terms for treatment and centre, and with baseline as the covariate. In the text part of the result section baseline means are based on raw data. All other means are adjusted for centre effects and baseline values. As a consequence of this adjustment, the baseline values in the figures are the common baseline means (means of all raw data from both treatment groups combined).

Baseline $\mathrm{FEV}_{1}$ was defined as the mean of the two $\mathrm{FEV}_{1}$ readings in the morning of the randomisation visit prior to administration of study medication. For the other test days the mean of two $\mathrm{FEV}_{1}$ readings at the end of the dosing interval for tiotropium was defined as trough $\mathrm{FEV}_{1}$ - that is, after inhalation of one dose of tiotropium but fourth dose of ipratropium. The trough $\mathrm{FEV}_{1}$ response was defined as the change from baseline in trough $\mathrm{FEV}_{1}$; this parameter after 13 weeks of treatment was chosen as the primary efficacy end point in order to establish the 24 hour duration of action of tiotropium. Since there was only one primary end point no adjustment for multiple comparisons is required. Additional bronchodilator parameters examined included the average and peak $\mathrm{FEV}_{1}$ response during the six hour observation period on the pulmonary function test days. Analogous definitions were used for FVC based parameters.

When a patient could not continue in the study because of deterioration of COPD, the missing efficacy data were estimated using the least favourable data observed prior to withdrawal from the study. For patients who missed study visits for other reasons, missing data were estimated using the patient's last observed data. For patients who did not complete all the pulmonary function measurements on a specific pulmonary function test day, linear interpolation was used to estimate random, missing, or middle spirometric measurements. Likewise, the minimum observed spirometric measurements on a specific test day were used to estimate values at the end of profiles that were missing because rescue medication was taken. Finally, the last available spirometric measurements were used to estimate values at the end of the profiles that were missing for reasons unrelated to the patient's treatment response.

\section{Results}

Of the 362 patients screened for entry into the study, 84 were not eligible. Of the remaining 288 patients, 191 were randomly assigned to the tiotropium group and 97 to the ipratropium group. The groups were well balanced for all demographic and baseline data (table 1). The withdrawal rates were similar in the two treatment groups (9.9\% for tiotropium, $11.3 \%$ for ipratropium; table 2). 
LUNG FUNCTION

The mean (SE) baseline $\mathrm{FEV}_{1}$ at the start of the treatment period did not differ between the two treatment groups (1.21 (0.03) 1 for the tiotropium group and $1.15(0.04) 1$ for the ipratropium group; $\mathrm{p}>0.05)$.

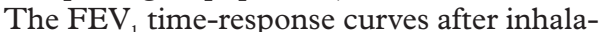
tion of the morning doses of tiotropium and ipratropium on days $1,8,50$, and 92 are shown in fig 1 . Thirty minutes after inhalation of the first dose of tiotropium there was a clinically relevant increase of $15 \%$ in the common baseline mean (1.19 1). The peak increase in $\mathrm{FEV}_{1}$ at three hours after dosing amounted to $23 \%$ while an improvement of $21 \%$ was still present six hours after dosing. The inhalation of the first dose of ipratropium resulted after $30 \mathrm{~min}$ utes in an increase of $18 \%$. The peak $\mathrm{FEV}_{1}$ increase of $21 \%$ was achieved between one and two hours after dosing, while after six hours the response had dropped to $9 \%$ above baseline. Starting three hours after inhalation the improvement in $\mathrm{FEV}_{1}$ was greater after tiotropium than after ipratropium $(\mathrm{p}<0.05)$.

On day 8 the mean trough increase in $\mathrm{FEV}_{1}$ over baseline was $13 \%$ for tiotropium and there was an additional improvement of $13 \%$ to the peak value three hours after inhalation. This profile was maintained on days 50 and 92 . The $\mathrm{FEV}_{1}$ time-response curves of ipratropium were similar on all study days. As a consequence, the $\mathrm{FEV}_{1}$ response at all time points on days 8,50 , and 92 , except at 0.5 and one hour after inhalation, was significantly greater after tiotropium than after ipratropium $(\mathrm{p}<0.05)$. Table 3 shows that the $\mathrm{FEV}_{1}$ trough, average over six hours, and peak response for tiotropium was greater than for ipratropium throughout the 13 week treatment period.

The results for FVC closely reflected those obtained for $\mathrm{FEV}_{1}$. The time-response curves for the four test days are shown in fig 2. In table 3 the FVC trough, averaged over six hours, and peak response for both test drugs are presented. Tiotropium performed consistently better than ipratropium. The differences in trough values were most pronounced $(p<0.001)$, whereas differences in peak increase did not reach statistical significance $(\mathrm{p}>0.05)$.

\section{PEAK EXPIRATORY FLOW}

Baseline values of morning and evening PEF did not differ between the groups $(p>0.05)$. Figure 3 shows the weekly means (SE) of morning and evening PEF during the 13 week treatment period. The improvement in both morning and evening PEF was greater in the tiotropium group than in the ipratropium group. The difference in morning PEF between the groups was statistically significant up through week $10(p<0.05)$. For evening PEF the difference reached statistical significance during the first seven weeks of the treatment period $(\mathrm{p}<0.05)$

CONCOMITANT MEDICATION

At baseline the mean (SE) use of rescue salbutamol was $2.7(0.2)$ puffs for the tiotropium group and $2.2(0.3)$ puffs per day for the
Table 4 Adverse events

\begin{tabular}{lcc}
\hline & $\begin{array}{c}\text { Tiotropium } \\
(n=191)\end{array}$ & $\begin{array}{c}\text { Ipratropium } \\
(n=97)\end{array}$ \\
\hline Total with any adverse event & $129(67.5)$ & $62(63.9)$ \\
General & $5(2.6)$ & 0 \\
$\quad$ Chest pain & $4(2.1)$ & $1(1.0)$ \\
Fatigue & $10(5.2)$ & $10(10.3)$ \\
Headache & $6(3.1)$ & $8(8.2)$ \\
Influenza-like symptoms & $4(2.1)$ & $1(1.0)$ \\
$\quad$ Pain, non-site specific & $28(14.7)$ & $10(10.3)$ \\
Upper respiratory & $6(3.1)$ & 0 \\
Dry mouth & $35(18.3)$ & $11(11.3)$ \\
Pharyngitis & & \\
$\quad$ Upper respiratory tract infection & $21(11.0)$ & $12(12.4)$ \\
Lower respiratory & $5(2.6)$ & $5(5.2)$ \\
COPD exacerbation & $5(2.6)$ & $2(2.1)$ \\
$\quad$ Cough & & \\
Pneumonia & &
\end{tabular}

Values are number (\%) of patients. No significant differences were seen between the two groups.

ipratropium group, the difference not being significant $(\mathrm{p}>0.05)$. In both treatment groups there was a drop in the use of rescue salbutamol, the reduction being greater in the tiotropium group than in the ipratropium group ( $\mathrm{p}<0.05$; fig 4$)$.

\section{SAFETY}

No significant differences were seen in the incidence of adverse events between the treatment groups (table 4). The only adverse event classified as drug related was dry mouth. This event was reported by 28 patients $(14.7 \%)$ in the tiotropium group and 10 patients $(10.3 \%)$ in the ipratropium group. Most reports were of mild intensity. In both the ipratropium and tiotropium groups the median time of onset was week 4 of treatment and the symptom persisted in about two thirds of the cases. None of the patients discontinued the study as a result of dry mouth.

In both treatment groups there were no clinically significant changes in vital signs, laboratory values, 12-lead ECG, or physical examination findings during treatment.

\section{Discussion}

This is the first long term study in which the bronchodilator effect of tiotropium has been investigated and directly compared with that of ipratropium in patients with moderate to severe airflow obstruction due to COPD. Over the 13 week treatment period $18 \mu \mathrm{g}$ tiotropium once daily via HandiHaler ${ }^{\circledR}$ achieved a significantly greater improvement in trough, peak, and average values of $\mathrm{FEV}_{1}$ and FVC than $40 \mu \mathrm{g}$ ipratropium four times daily. These data confirm the results of previous single dose studies $^{910}$ that tiotropium has a bronchodilating effect of at least 24 hours. During the maintenance therapy with tiotropium the values of $\mathrm{FEV}_{1}$ and FVC never returned to baseline values. There was still an improvement in trough $\mathrm{FEV}_{1}$ and FVC response 24 hours after the previous dose that was even better than the improvement in $\mathrm{FEV}_{1}$ and FVC found six hours after inhalation of ipratropium. Measurements after the first doses of both compounds showed that ipratropium had a more rapid onset of action than tiotropium. However, during maintenance therapy this difference was no longer of importance, as the "acute on chronic" effect of 
tiotropium achieved greater bronchodilation than ipratropium. Furthermore, after both tiotropium and ipratropium the improvements in FVC were similar to those in $\mathrm{FEV}_{1}$. It is generally thought that anticholinergic agents produce their bronchodilating effect mainly in the central airways. ${ }^{1516}$ Nevertheless, this increase in FVC might be interpreted as a diminution of air trapping and of closure of the small airways. ${ }^{17}$

In keeping with the results of the clinic lung function, improvement in morning and evening PEF monitored at home was better in the tiotropium group and also the decrease in use of concomitant salbutamol was greater in the tiotropium group. It is known that in COPD the relationship between PEF and $\mathrm{FEV}_{1}$ is poor and PEF may underestimate the degree of airways obstruction because of the airway collapsibility present in this disorder. ${ }^{4}{ }^{18}$ However, serial PEF measurements are of value in assessing treatment response. ${ }^{19}$ Using weekly means of PEF recordings in the tiotropium group steady state was reached after two weeks and sustained during the treatment period, whereas in the ipratropium group PEF showed a tendency to increase throughout the 13 week period. Rennard et $a l^{20}$ also found in their meta-analysis that extended administration of ipratropium is associated with improved baseline lung function.

For the present long term study the $18 \mu \mathrm{g}$ dose of tiotropium was selected. This choice was based on the results of a recent four week clinical trial showing that this dose combines effective bronchodilation for 24 hours with a low side effect profile. ${ }^{21}$ The pharmacokinetic steady state was reached within approximately 25 days and there was no evidence of long term accumulation of the drug in the plasma or urine..$^{22}$ Our data confirm that, with respect to both bronchodilator effect and safety, $18 \mu \mathrm{g}$ once daily is an appropriate regimen for maintenance therapy. In terms of both the trough and the acute response, pharmacodynamic steady state was reached within one week of treatment. This steady state was sustained throughout the treatment period.

Tiotropium appears to be a safe drug during long term treatment. No systemic cholinergic adverse effects were observed. The only drug related adverse event was dry mouth, reported by $14.7 \%$ of the patients, which is slightly higher than the $10.3 \%$ incidence in the ipratropium group. None of the patients withdrew from the study because of this effect.

At present the official ATS guidelines ${ }^{4}$ recommend regular use of anticholinergics as first line treatment in patients with COPD suffering from continuing symptoms. The present study shows that tiotropium has important and significant advantages over ipratropium. Tiotropium is more potent, has a longer duration of action, and is able to produce a permanent improvement in baseline lung function. It allows once daily dosing which is convenient for patients with COPD and may enhance compliance with treatment. However, we are aware that, in addition to spirometric indices, there are other outcome parameters including improvement in symptoms, exercise performance, and gain in health and well being that are relevant to the patient but are poorly related to improvement in $\mathrm{FEV}_{1}$ and $\mathrm{FVC}^{2}$ The issues concerning health related quality of life will be addressed in the analysis of the results after one year of treatment.

In conclusion, $18 \mu \mathrm{g}$ tiotropium once daily was significantly more effective than $40 \mu \mathrm{g}$ ipratropium four times daily in improving trough and peak lung function over the 13 week treatment period. The safety profile of tiotropium was similar to ipratropium. These data support the use of tiotropium as first line treatment for the long term maintenance treatment of patients with airflow obstruction due to COPD.

Funding: This study was supported by a grant from Boehringer Ingelheim BV, Alkmaar, The Netherlands.

1 Siafakas NM, Vermeire P, Pride NB, et al. Optimal assessment and management of chronic obstructive pulmonary disease (COPD): ERS consensus statement. Eur Respir 7 1995;8:1398-420.

2 Hay JG, Stone P, Carter J, et al. Bronchodilator reversibility, exercise performance and breathlessness in stable chronic obstructive pulmonary disease. Eur Respir f 1992;5:65964.

3 Gross NJ, Skorodin MS. Anticholinergic, antimuscarinic bronchodilators. Am Rev Respir Dis 1984;129:856-70.

4 ATS Statement. Standards for the diagnosis and care of patients with chronic obstructive pulmonary disease. $A m \mathcal{F}$ Respir Crit Care Med 1995;152: S77-120

5 Gross NJ. Ipratropium bromide. N Engl f Med 1988;319: 486-94.

6 Barnes PJ. Muscarinic receptor subtypes in airways. Life Sci 1993;52:521-7.

7 Disse B, Reichl R, Speck G, et al. Ba679 Br, a novel anticholinergic bronchodilator. Life Sci 1993;52:537-44.

8 Takahaski T, Belvisi MG, Patel H, et al. Effect of BA679 Br, a novel long-acting anticholinergic agent, on cholinergic neurotransmission in guinea pig and human airways. Am $\mathcal{F}$ Respir Crit Care Med 1994;150:1640-5.

9 Maesen FPV, Smeets JJ, Costongs MAL, et al. BA679 Br, a new long-acting antimuscarinic bronchodilator: a pilot dose-escalation study. Eur Respir f 1993;6:1031-6.

10 Maesen FPV, Smeets JJ, Sledsens TJH, et al. Tiotropium bromide, a new long-acting antimuscarinic bronchodilator: a pharmacodynamic study in patients with chronic obstructive pulmonary disease (COPD). Eur Respir F 1995; 8:1506-13.

11 O'Connor BJ, Towse LJ, Barnes PJ. Prolonged effect of tiotropium bromide on metacholine-induced bronchoconstriction in asthma. Am $\mathcal{F}$ Respir Crit Care Med 1996;154: 87riction

12 Quanjer PH, Tammeling GJ, Cotes JE, et al. Lung volumes and forced ventilatory flow. Eur Respir f 1993;6(Suppl 16): $5-40$

13 Chodosh S, Flanders J, Serby CW, et al. Effective use of HandiHaler $\circledR$ dry powder inhalation system over a range of COPD severity. Am f Respir Crit Care Med 1999; 159(Suppl):A524.

14 American Thoracic Society. Lung function testing: selection of reference values and interpretative strategies. Am Rev Respir Dis 1991:144:1202-18.

15 Ingram RH, Wellman JJ, Mc Fadden ER, et al. Relative contribution of large and small airways to flow limitation in normal subjects before and after atropine and isoproterenol. F Clin Invest 1977;59:696-703.

16 Barnes PJ, Basbaum CB, Nadel JA. Autoradiographic localization of autonomic receptors in airway smooth muslocalization of autonomic receptors in airway smooth mus-
cle. Marked differences between large and small airways. Am Rev Respir Dis 1983;127:758-62.

17 Macklem PT. The physiology of small airways. Am f Respir Crit Care Med 1998;157:S181-3.

18 Gibson GJ, Kelly CA. Relation between $\mathrm{FEV}_{1}$ and peak expiratory flow in patients with chronic airflow obstruction. Thorax 1988;43:335-6.

19 Mitchell DM, Gildeh P, Dimond AH, et al. Value of serial peak expiratory flow measurements in assessing treatment response in chronic airflow limitation. Thorax 1986;41: 606-10

20 Rennard SL, Serby CW, Ghafouri M, et al. Extended therapy with ipratropium is associated with improved lung function in patients with COPD. A retrospective analysis of data from seven clinical trials. Chest 1996;110:62-70.

21 Littner M, Auerbach D, Campbell S, et al. The bronchodilator effects of tiotropium in stable COPD. Am $\mathcal{F}$ Respir Crit Care Med 1997;155(Suppl):A282.

22 Disse B, Rominger K, Serby CW, et al. The pharmacokinetic (PK) profile of tiotropium during long-term treatment in stable COPD. Am f Respir Crit Care Med 1999;159(Suppl): A524. 